\title{
Frequency domain analysis to detect common cycle in housing price and trading volume
}

\author{
Seungryul Ma*
}

\begin{abstract}
요 약
The movements of housing prices and trading volume have long-term cycles. Thus, it can be presumed that there would be a close relationship between the cyclic components embedded in these two variables. However, it has been challenging to find studies that analyzed the cyclical characteristics and the relationship between the common cycles embedded in these two variables. This study, in contrast to previous studies that used methodologies in the time domain analysis to confirm the correlation and lead-lag relationship between housing prices and trading volume, analyzed, from different perspectives, the cyclical characteristics embedded in these two variables, using spectral analysis in the frequency domain. When forecasting cycles in housing prices and trading volume, for comparison, we added the results of the $\operatorname{VAR}(\mathrm{p})$ model analysis in the time domain to the results of the spectral analysis in the frequency domain. We could confirm that there were common cycles between the movements of housing prices and trading volume. Further, we confirmed that the movement of trading volume slightly precedes that of housing prices. According to our results, when the housing price has an upward trend, the housing market was expected to face a slow speed of an increase in housing prices while a decrease in trading volume for the time being after 2019. However, after 2020, both the trading volume and housing prices were expected to witness a relatively rapid increase. Ultimately, we improved the rationality of the forecasting results of future cycles by confirming the results from the time and frequency domain analyses.
\end{abstract}

Key words: common cycle, housing price, trading volume, spectral analysis, harmonic analysis

\section{Introduction}

In housing market, it is well known that there is a close relationship between housing prices and trading volume. For example, if we assume that there is positive correlation between housing

\footnotetext{
* Director, SonSa Research Institute, E-mail: samhan12@hanmail.net

(c) Copyright 2021 Korea Housing \& Urban Guarantee Corporation. This is an Open Access article distributed under the terms of the Creative Commons Attribution-NonCommercial-NoDerivatives License (http://creativecommons.org/licenses/by-nc-nd/4.0/) which permits unrestricted non-commercial use, distribution, and reproduction in any medium, provided the original work is properly cited.
} 
prices and trading volume as well as the movement of trading volume leads that of housing prices, we can expect that trading volume increase will be followed by housing prices increase and trading volume decrease will be followed by housing prices decrease. If this happens, we could presume the future direction of housing price through checking the direction of trading volume in housing market.

For this reason, many studies have been conducted to confirm a close correlation or lead-lag relationship between housing prices and trading volume in long-term movements. Stein (1995) showed the research result that trading volume decreased when housing price decreased due to effects of down payment home owner paid. Genesove and Mayer (2001) also showed the phenomenon that trading volume decreased when housing price decreased, and asserted that although this phenomenon could not be explained by perfect asset market model but it could be explained by seller's propensity of loss aversion or equity constraints. Clayton et al. (2010) showed that there was two-way Granger causation between housing prices and trading volume. Leung and Peng (2005) showed that there was one-way Granger causation from trading volume to housing prices in commercial building.

In the studies that analyzed Korean housing market. Lim (2011) showed that the causality appeared bidirectional and there was a positive correlation between housing prices and trading volume. Lim (2014) confirmed that a lead-lag relationship or co-movement between housing prices and trading volume had shown different results by region. Like these, the previous studies conducted to confirm the relationship between housing prices and trading volume mainly focused on a close correlation and lead-lag relationship in time domain.

Meanwhile, we can say that the movements of housing prices and trading volume have long-term cycles. So, we also can presume that there would be a close relationship between cyclic components embedded in these two variables. But, until now, it is difficult to find studies which analyzed cyclical characteristics and the relationship under common cycles embedded in these two variables.

In this analysis, unlike the previous studies conducted to confirm the correlation and lead-lag relationship between housing prices and trading volume using the methodologies in time domain analysis, we are trying to interpret from different points of view through analyzing cyclical characteristics embedded in these two variables by using spectral analysis in frequency domain. Through spectral analysis, we can show the lead-lag relationship between housing prices and trading volume under common cycles visually.1) After identifying common cycles embedded in these two variables, if we could confirm a close relationship under 
common cycles, it is expected that we could confirm the current position of two variables under long-term cycles and forecast future direction of the cycles.

When we forecast cycles in housing prices and trading volume, for the purpose of comparison, we added the results of $\operatorname{VAR}(\mathrm{p})$ model analysis in time domain in addition to the results of the spectral analysis in frequency domain. Ultimately, we could improve the rationality about the forecasting results of future cycles by confirming the results from time domain and frequency domain analysis concurrently. The paper is organized as follows. In Section 2, we briefly describe the methodology and data we use in our analysis. In Section 3, we describe the results of our analysis focusing on common cycles embedded in two variables. Finally, the paper is concluded in Section 4.

\section{Methodology and Data}

\section{Spectral Analysis}

To detect cycles in time series data, we can use the methodologies in frequency domain such as harmonic analysis, periodogram ana- lysis, and spectral analysis. After detecting common cycles embedded in time series $x_{t}$ and $y_{t}$, to confirm long-term relationship between these two time series under common cycles, we can conduct cross spectral analysis. Through the cross spectral analysis, we will obtain a squared coherence spectrum to estimate the percentage of shared variance between the two time series at a particular frequency band and we will also obtain a phase spectrum to estimate a phase relationship (or time lag) between the two time series within each frequency band (Wei, 1990; Warner, 1998). The squared coherence $\left(K_{x y}(w)^{2}\right)$ can be calculated as $\langle$ Eq. 1〉 below.

$$
K_{x y}(w)^{2}=\frac{f_{x y}(w)^{2}}{f_{x}(w) f_{y}(w)}
$$

Where, $f_{x y}(w)$ : cross spectrum between $x_{t}$ and $y_{t} ; f_{x}(w)$ : spectrum of $x_{t} ; f_{y}(w)$ : spectrum of $y_{t} ; w$ : angular frequency $(2 \pi / \tau) ; \tau$ : period or cycle length.

The phase $\left(\phi_{x y}(w)\right)$ can be calculated as $\langle$ Eq. 2〉 below.

1) Related to this, we can find the previous studies which used spectral analysis to confirm the relationship between housing price and other variables except for trading volume. Cho and Ma (2006) analyzed the relationship between housing value and interest rate and $\mathrm{Ma}$ (2016) analyzed the relationship among housing price, business cycle, and unsold housing. 


$$
\phi_{x y}(w)=\tan ^{-1}\left[\frac{-q_{x y}(w)}{c_{x y}(w)}\right]
$$

Where, $-q_{x y}(w)$ : imaginary parts of $f_{x y}(w)$; $c_{x y}(w)$ : real parts of $f_{x y}(w)$.

If we identify the cycles embedded in the time series using periodogram analysis, we could conduct harmonic analysis to show the identified cycle components visually. Harmonic analysis model for time series which includes sine $(\sin )$ and cosine (cos) functions can be expressed as 〈Eq. 3〉.

$$
x_{t}=\mu+A \cos (w t)+B \sin (w t)+\varepsilon_{t} \quad\langle\text { Eq. 3〉 }
$$

Where, $\mu$ : mean value; $t$ : observations $(t=0,1, \cdots, N) ; \varepsilon_{t}: W N\left(0, \sigma^{2}\right)$

The formal model for the periodogram is an extension of the harmonic analysis model. As we can see in $\langle$ Eq. 4〉, the periodogram model represents the time series as a sum of $\mathrm{N} / 2$ periodic components.

$$
\begin{aligned}
& x_{t}=\mu+\sum_{i}\left[A_{i} \cos \left(w_{i} t\right)+B_{i} \sin \left(w_{i} t\right)\right], \\
& \text { for } i=1,2,3, \cdots, N / 2
\end{aligned}
$$

Where, $\cos \left(w_{i} t\right)$ : the cosine function of frequency $w_{i} ; \sin \left(w_{i} t\right)$ : the sine function of frequency $w_{i}$.
Periodogram analysis is a useful technique to search for hidden periodicities through assessing whether there is a strong cyclic component in a time series. Meanwhile, spectral analysis techniques were developed to reduce the possible problem of sampling error in periodogram analysis. An estimated power spectrum in the spectral analysis is a smoothed version of the periodogram. We use these smoothed spectrums for and when we calculate the squared coherence $\left(K_{x y}(w)^{2}\right)$ and the phase $\left(\phi_{x y}(w)\right)$ in the cross spectral analysis.

\section{2. $\operatorname{VAR}(p)$ Model}

$\operatorname{VAR}(\mathrm{p})$ model allows for cross-variable dynamics. In an $\mathrm{N}$-variable vector autoregression of order $\mathrm{p}(\operatorname{VAR}(\mathrm{p}))$, we estimate $\mathrm{N}$ different equations. In $\operatorname{VAR}(\mathrm{p})$ model, each variable is related not only to its own past, but also to the past of all the other variables in the system. For example, we have two equations as in $\langle$ Eq. 5〉 and $\langle$ Eq. 6〉 in a two-variable VAR(p) model (Diebold, 2001).

$$
x_{t}=\alpha_{1}+\sum_{j=1}^{p} \beta_{j} x_{t-j}+\sum_{j=1}^{p} \gamma_{j} y_{t-j}+u_{1, t}\langle\text { Eq. 5〉 }
$$

$$
y_{t}=\alpha_{2}+\sum_{j=1}^{p} \delta_{j} x_{t-j}+\sum_{j=1}^{p} \lambda_{j} y_{t-j}+u_{2, t}\langle\text { Eq. 6 }\rangle
$$

$$
\text { Where, } u_{1, t} \sim W N\left(0, \sigma_{1}^{2}\right)
$$




$$
\begin{aligned}
& u_{2, t} \sim W N\left(0, \sigma_{2}^{2}\right) \\
& \operatorname{cov}\left(u_{1, t}, u_{2, t}\right)=\sigma_{12}
\end{aligned}
$$

\section{Data Analysis}

This analysis was conducted to confirm the relationship between long-term cycles embedded in both growth rate of housing prices and trading volume. We can use monthly time series data of apartment price index and apartment trading volume from the database of Korea Real Estate Board2). To identify long-term cycles embedded in the time series, we used the year-on-year increase rates of apartment price index as the proxy variable of housing price change rates. And as the proxy variable of trading volume, we used the twelvemonth accumulated monthly apartment trading volume.

In this analysis, due to different characteristics of housing prices and trading volume by region, the region in our analysis is divided into four regions as follows. (1) Total (Whole country), (2) Seoul Metropolitan (Seoul, Incheon, Gyunggi), (3) 5 Big Cities (Busan, Daegu, Gwangju, Daejeon, Ulsan), (4) Non Metropolitan (Gangwon, Chungbuk, Chungnam, Jeonbuk, Jeonnam, Gyungbuk, Gyungnam, Jeju).
To find long-term relationship between housing price change rates and trading volume after identifying common cycles embedded in these two variables, we stabilized the pattern of time series of these two variables by eleminating the trends in these two variables using Hodrick-Prescott filtering method. As we can see from the Figures below, all modified variables show the pattern of fluctuating up and down centering around the mean value of zero. And then, we finally standardize these two variables to avoid the problem could be resulted from different units 3 ).

$\langle$ Figure 1〉 show the year-on-year increase rates of housing price (g) and standardized housing price change rates $(\mathrm{gN})$ by regions from 01.2007 to 10.2018 .

We could confirm that the cycles in the standardized housing price change rates $(\mathrm{gN})$ show similar pattern regardless of region in $\langle$ Figure 1〉. The cycles of standardized accumulated trading volume (VolN) in 〈Figure 2〉 also show similar pattern regardless of region. Meanwhile, as we can see in $\langle$ Figure 3$\rangle$, the pattern of long-term cycles in standardized housing price change rates $(\mathrm{gN})$ show similar pattern to the standardized accumulated trading volume (VolN) in all four regions from 01.

2) In our analysis, we used apartment data as the proxy of house data considering it's absolute weight in the trading volume and number among house types.

3) We generated standardized series $\left(x_{t}^{*}\right)$ by subtracting mean value $(\mu)$ from the raw value $\left(x_{t}\right)$ and then dividing it by standard deviation $(\sigma)$. That is $\left.x_{t}^{*}=\left(x_{t}-\mu\right) / \sigma\right)$. 


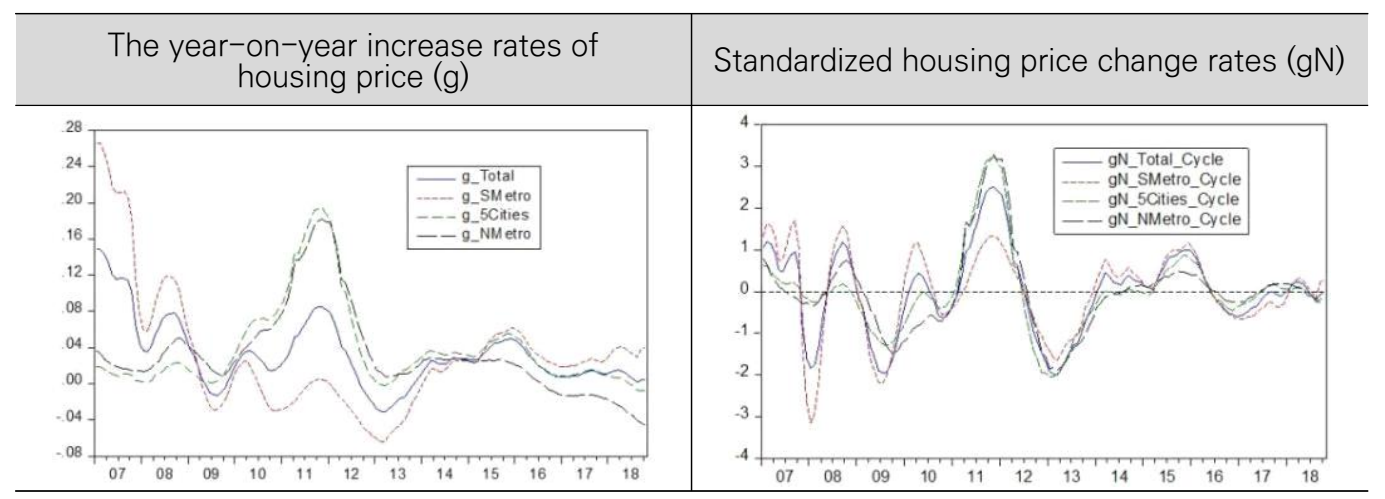

Total: whole contury; SMetro: Seoul Metropolitan area; 5Cities: 5 big cities; NMetro: nonmetropolitan.

$\langle$ Figure 1〉 Housing price change rates

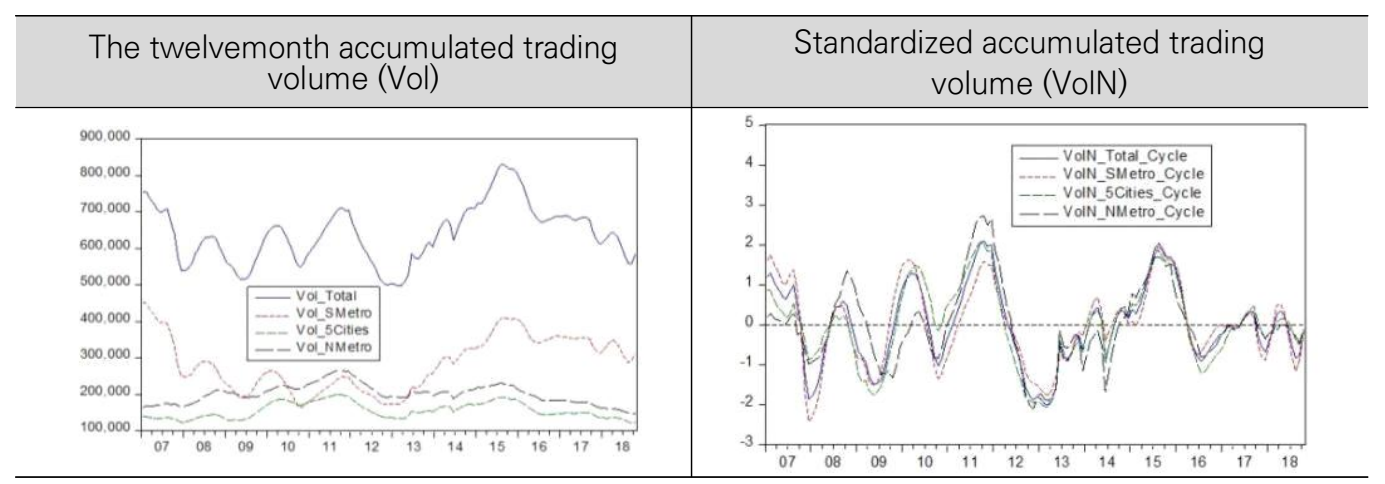

Total: whole contury; SMetro: Seoul Metropolitan area; 5Cities: 5 big cities; NMetro: nonmetropolitan.

$\langle$ Figure 2〉 Twelvemonth accumulated trading volume

2007 to 10.2018 .

In this analysis, we could find cyclical component embedded in these two variables by using spectral analysis and then identify if there is common cycles in two variavles. Finally, we could confirm close relationship between these two variables under common cycles through the values of phase and squared coherence.

\section{Results of Analysis}

\section{Unit Root Test}

The standardized variables we used in our analysis show the pattern of fluctuating up and down centering around the mean value of zero because we stabilized the pattern of time series of these two variables by eleminating 


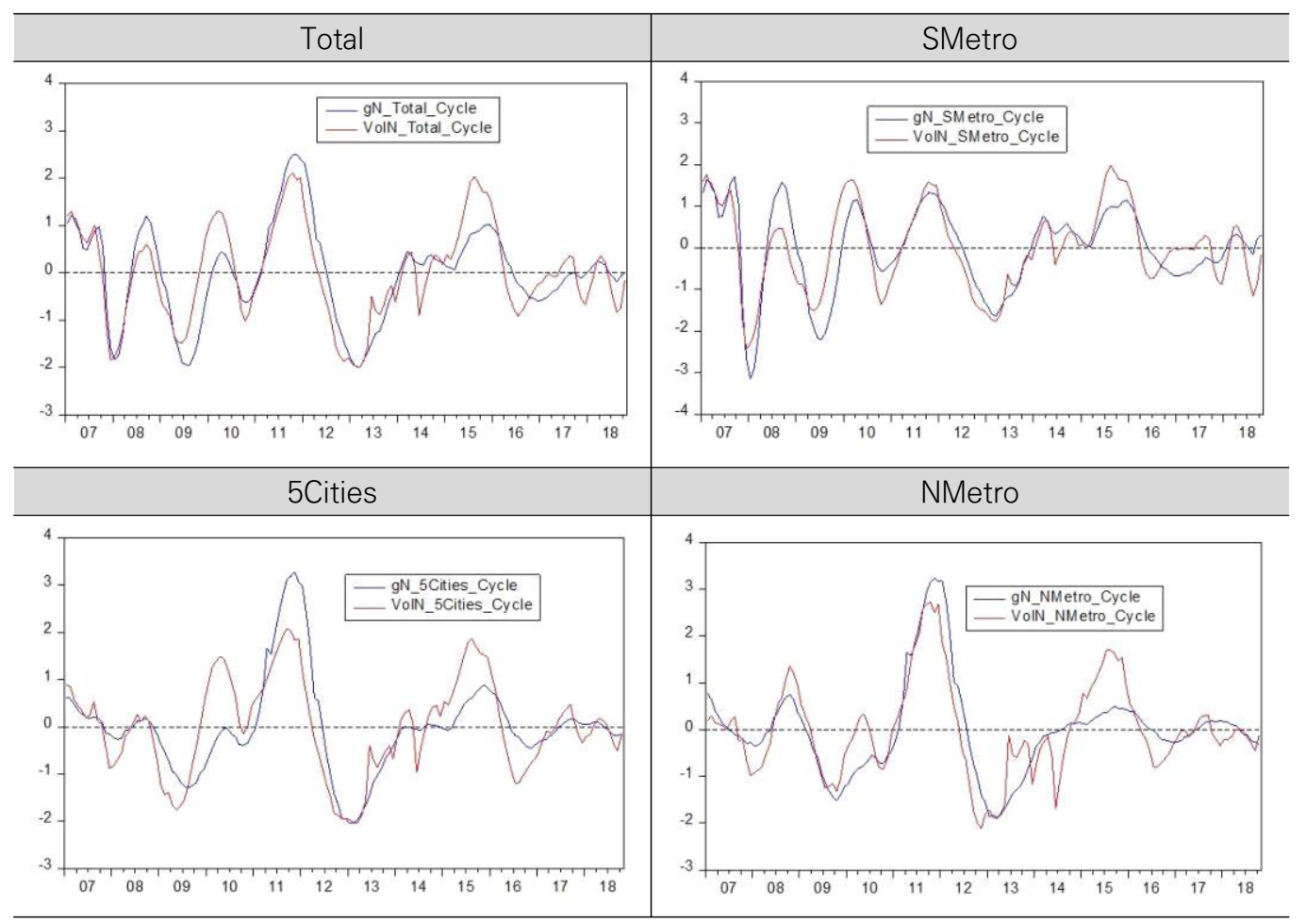

Total: whole contury; SMetro: Seoul Metropolitan area; 5Cities: 5 big cities; NMetro: nonmetropolitan.

$\langle$ Figure 3$\rangle$ The standardized housing price change rates $(\mathrm{gN})$ and accumulated trading volume (VoIN)

the trends in these two variables using Hodrick-Prescott filtering method. To confirm the stability of these two variables, we conducted unit root test by using augmented Dickey-Fuller unit root test (ADF) method.

As we can see in 〈Table 1〉, the results of ADF test show us that both standardized housing price change rates $(\mathrm{gN})$ and standardized accumulated trading volume (VolN) are stationary time series regardless of regions because all the statistics reject the null hypothesis under $5 \%$ level of test critical values.

\section{Moving Directions of Time Series}

From previous Figures, we can see that the cyclical movements in both $\mathrm{gN}$ and VolN show similar pattern as we could expect generally. That is, trading volume increase will be followed by housing prices increase and trading volume decrease will be followed by housing prices decrease. On the other hand we could expect that housing prices increase (decrease) will be followed by trading volume increase (decrease) because demand for home buying increase (decrease). So, we could 
$\langle$ Table 1〉 The results of ADF test

\begin{tabular}{c|c|c|c|c|c}
\hline gN & t-Stat. & Prob. & VoIN & t-Stat. & Prob. \\
\hline gN_Total & -4.4540 & 0.0004 & VolN_Total & -4.4155 & 0.0004 \\
\hline gN_SMetro & -6.7637 & 0.0000 & VolN_SMetro & -6.1524 & 0.0000 \\
\hline gN_5Cities & -4.5882 & 0.0002 & VoIN_5Cities & -3.1563 & 0.0248 \\
\hline gN_NMetro & -4.8718 & 0.0001 & VoIN_NMetro & -2.9208 & 0.0455 \\
\hline
\end{tabular}

1) We reported the results estimated by using the formular which has only intercept in test equation.

2) Null hypothesis: gN has a unit root or VoIN has a unit root.

ADF: augmented Dickey-Fuller; Total: whole contury; SMetro: Seoul Metropolitan area; 5Cities: 5 big cities; NMetro: non-metropolitan.

$\langle$ Table 2〉 The results of Granger causality test

\begin{tabular}{c|c|c|c|c|c|c}
\hline \multirow{2}{*}{ Total } & & lag2 & lag3 & lag4 & lag5 & lag6 \\
\cline { 2 - 6 } & gN $\nrightarrow$ VolN & 0.0002 & 0.0001 & 0.0003 & 0.0004 & 0.0011 \\
\hline \multirow{3}{*}{ SMetro } & VolN $\nrightarrow \mathrm{gN}$ & 0.0291 & 0.0493 & 0.1072 & 0.1585 & 0.3686 \\
\cline { 2 - 7 } & gN $\nrightarrow$ VolN & 0.2688 & 0.0636 & 0.0131 & 0.0256 & 0.0509 \\
\hline \multirow{3}{*}{5 Cities } & VolN $\nrightarrow \mathrm{gN}$ & 0.0194 & 0.0293 & 0.0085 & 0.0076 & 0.0902 \\
\cline { 2 - 7 } & gN $\nrightarrow$ VolN & 0.0000 & 0.0005 & 0.0028 & 0.0025 & 0.0086 \\
\hline \multirow{2}{*}{ NMetro } & VolN $\nrightarrow \mathrm{gN}$ & 0.0007 & 0.0835 & 0.1707 & 0.1156 & 0.1318 \\
\cline { 2 - 7 } & $\mathrm{gN} \nrightarrow \mathrm{VoIN}$ & 0.0000 & 0.0000 & 0.0003 & 0.0006 & 0.0009 \\
\hline
\end{tabular}

1) All numbers represent probability of F-statistic in Granger causality test.

2) The dark cells show the cases of rejecting the null hypothesis under $5 \%$ level of test critical values.

3) Null hypothesis: "gN does not Granger cause VolN" or "VolN does not Granger cause gN".

Total: whole contury; SMetro: Seoul Metropolitan area; 5Cities: 5 big cities; NMetro: nonmetropolitan.

presume that the cyclicical movement of these two variables would have two-way causation. To confirm the moving directions between two time series, we conducted Granger causality test.

According to the results of Granger causality test, we could say that there are two-way causation between the time series of $\mathrm{gN}$ and VolN regardless of regions.

\section{The Results of Spectral Analysis}

〈Table 3〉 show the results of periodogram 
analysis we conducted to identify the common cycles embedded in two variables 4 ).

Among the results of periodogram analysis, the idenfied common cycles embedded in $\mathrm{gN}$ and VolN were 20 month and 48 month in Total, Smetro, and Nmetro area. But, the idenfied common cycles in 5Cities were 24 month and 48 month.

Under the identified common cycles, we could confirm close relationship between $\mathrm{gN}$ and VolN through the values of phase and squared coherence we generated by using cross spectral analysis5).

As we can see in 〈Table 4〉 almost all values of phase show small negative values close to zero. This result tells that, in the aspect of common cycle, the movement of trading volume precedes slightly that of housing price change rate.
For example, in the case of Total (whole country), the movement of trading volume precedes about 3 months $(=(-0.2 / \pi) \times 48)$ the movement of housing price change rate in the aspect of 48 month commom cycle and the movement of trading volume precedes about 1.9 months $(=-0.3 / \pi) \times 20)$ the movement of housing price change rate in the aspect of 20 month commom cycle6). Meanwhile, the values of squared coherence, $0.58-0.87$, tell us that there is a very close relationship between two variables in the aspect of common cycles7).

If we conduct harmonic analysis using the cycles we idenfied through periodgram analysis, we could confirm visually the cyclic components embedded in the time series. 〈Table 5) show the results of harmonic analysis conducted by using the time series of housing price change rates.

〈Table 3〉 Identified long-term cycles by using periodogram analysis

\begin{tabular}{c|c|c}
\hline Region & gN & VolN \\
\hline Total & 20 month, 48 month & 20 month, 48 month \\
\hline SMetro & 20 month, 48 month & 20 month, 48 month \\
\hline 5Cities & 24 month, 48 month & 24 month, 48 month \\
\hline NMetro & 20 month, 48 month & 20 month, 48 month \\
\hline
\end{tabular}

Total: whole contury; SMetro: Seoul Metropolitan area; 5Cities: 5 big cities; NMetro: non-metropolitan.

4) Refer to Appendix 1 to see the shape of periodogram.

5) Refer to Appendix 2 to see the results of cross spectral analysis more concretely.

6) Phase indicates the timing of peaks in the time series $x$ relative to peaks in the time series $y$ at a given frequency (Warner, 1998).

7) Coherence indicates the percentage of shared variance between the two time series at a particular frequency (Warner, 1998). 
$\langle$ Table 4〉 The values of phase and squared coherence

\begin{tabular}{c|c|c|c}
\hline \multirow{2}{*}{ Region } & Common cycle & Phase & Squared coherence \\
\hline \multirow{2}{*}{ Total } & 20 month & -0.3 & 0.82 \\
\cline { 2 - 4 } & 48 month & -0.2 & 0.82 \\
\hline \multirow{2}{*}{ SMetro } & 20 month & -0.3 & 0.75 \\
\cline { 2 - 4 } & 48 month & 0.0 & 0.75 \\
\hline \multirow{2}{*}{ 5Cities } & 24 month & -0.2 & 0.58 \\
\cline { 2 - 4 } & 48 month & -0.5 & 0.78 \\
\hline \multirow{2}{*}{ SMetro } & 20 month & -0.5 & 0.77 \\
\cline { 2 - 4 } & 48 month & -0.2 & 0.87 \\
\hline
\end{tabular}

Total: whole contury; SMetro: Seoul Metropolitan area; 5Cities: 5 big cities; NMetro: nonmetropolitan.

〈Table 5〉 The results of harmonic analysis: Housing price change rates (gN) (2007.01-2018.10)

\begin{tabular}{c|c|c|c|c}
\hline & Total & SMetro & 5Cities & NMetro \\
\hline $\cos (2 \pi t / 20)$ & $-0.244(-2.802)$ & $-0.240(-2.610)$ & & $-0.183(-1.969)$ \\
\hline $\sin (2 \pi t / 20)$ & $-0.354(-4.053)$ & $-0.479(-5.192)$ & & $-0.163(-1.762)$ \\
\hline $\cos (2 \pi t / 24)$ & & & $0.4054(4.806)$ & \\
\hline $\sin (2 \pi t / 24)$ & & & $-0.153(-1.835)$ & \\
\hline $\cos (2 \pi t / 48)$ & $-0.554(-6.391)$ & $-0.308(-3.371)$ & $-0.651(-7.810)$ & $-0.742(-8.040)$ \\
\hline $\sin (2 \pi t / 48)$ & $0.6445(7.325)$ & $0.6340(6.823)$ & $0.6233(7.376)$ & $0.4087(4.364)$ \\
\hline$A d j R^{2}$ & 0.4584 & 0.3959 & 0.5002 & 0.3862 \\
\hline
\end{tabular}

Numbers in the parenthesis represent t statistics.

Total: whole contury; SMetro: Seoul Metropolitan area; 5Cities: 5 big cities; NMetro: nonmetropolitan.

〈Table 6〉 show the results of harmonic analysis conducted by using the time series of trading volume.

\section{The Estimated Results of VAR Model}

In this analysis, we forecasted future values of housing price change rates $(\mathrm{gN})$ and trading volume (VolN) by using VAR model to compare with the forecasted results from harmonic analysis. 〈Table 7〉 show the estimated parameters of bivariate VAR model by regions.

From the results of Granger causality test, we could confirm that there would be a 
〈Table 6〉 The results of harmonic analysis: Trading volume (VoIN) (2007.01-2018.10)

\begin{tabular}{c|c|c|c|c}
\hline & Total & SMetro & 5Cities & NMetro \\
\hline $\cos (2 \pi t / 20)$ & $-0.355(-3.960)$ & $-0.313(-3.181)$ & & $-0.381(-4.248)$ \\
\hline $\sin (2 \pi t / 20)$ & $-0.368(-4.112)$ & $-0.378(-3.845)$ & & $-0.349(-3.889)$ \\
\hline $\cos (2 \pi t / 24)$ & & & $0.3754(4.724)$ & \\
\hline $\sin (2 \pi t / 24)$ & & & $-0.251(-3.192)$ & \\
\hline $\cos (2 \pi t / 48)$ & $-0.322(-3.624)$ & $-0.191(-1.958)$ & $-0.260(-3.318)$ & $-0.580(-6.501)$ \\
\hline $\sin (2 \pi t / 48)$ & $0.6975(7.728)$ & $0.5932(5.987)$ & $0.9166(11.513)$ & $0.4967(5.490)$ \\
\hline$A d j R^{2}$ & 0.4300 & 0.3132 & 0.5563 & 0.4275 \\
\hline
\end{tabular}

Numbers in the parenthesis represent t statistics.

Total: whole contury; SMetro: Seoul Metropolitan area; 5Cities: 5 big cities; NMetro: nonmetropolitan.

bidirectional movement between the time series of $\mathrm{gN}$ and VolN regardless of regions. Related to this, when we see the estimated parameters of VAR model, we could confirm that the time series of $\mathrm{gN}$ is influenced by the lagged values of VolN as well as its own lagged values. At the same time, we could also confirm that the time series of VolN is influenced by the lagged values of $\mathrm{gN}$ as well as its own lagged values.

In the aspect of long-term cycles we analyzed by using cross spectral analysis, we could confirm that the movement of trading volume precedes that of housing price change rates. But, according to the results of VAR model, we could presume that the lead-lag relationship between the time series of $\mathrm{gN}$ and VolN could be reversed as time goes on in the aspect of short-term movements.

\section{Comparison of Forecasting Results}

In our analysis, if we use the parameters estimated in the harmonic analysis, we could forecast long-term common cycles embedded in the time series of $\mathrm{gN}$ and VolN after 11.2018. And then, if we use the parameters estimated in the VAR model, we could also forecast long-term movements of cyclical components in the time series of $\mathrm{gN}$ and VolN after 11.2018 .

If we compare the forecasted values generated by using harmonic analysis and VAR model, we could get more reasonable projection about the environment of future housing market.

\section{1) Housing market in whole country}

In the aspect of long-term common cycles in $\mathrm{gN}$ and VolN in whole country, we could 
〈Table 7〉 The estimated results of VAR(p) model (2007.01-2018.10)

\begin{tabular}{|c|c|c|c|c|}
\hline & \multicolumn{2}{|c|}{ Total: VAR(2) } & \multicolumn{2}{|c|}{ SMetro: VAR(4) } \\
\hline & $g N_{t}$ & $\operatorname{Vol} N_{t}$ & $g N_{t}$ & $\operatorname{Vol} N_{t}$ \\
\hline$g N_{t-1}$ & $1.5437(18.56)$ & $0.4858(4.074)$ & $1.6164(14.739)$ & $0.2002(1.812)$ \\
\hline$g N_{t-2}$ & $-0.6348(-8.100)$ & $-0.4841(-4.308)$ & $-0.9835(-4.877)$ & $-0.580(-2.854)$ \\
\hline$g N_{t-3}$ & & & $0.2786(1.374)$ & $0.5457(2.671)$ \\
\hline$g N_{t-4}$ & & & $-0.112(-1.016)$ & $-0.254(-2.296)$ \\
\hline $\operatorname{Vol} N_{t-1}$ & $0.1790(2.650)$ & $1.2362(12.762)$ & $0.1785(1.641)$ & 1.6694 (15.233) \\
\hline $\operatorname{Vol} N_{t-2}$ & $-0.1459(-2.151)$ & $-0.3619(-3.722)$ & $0.0351(0.1777)$ & $-0.725(-3.627)$ \\
\hline $\operatorname{Vol} N_{t-3}$ & & & $-0.341(-1.715)$ & $-0.200(-1.000)$ \\
\hline $\operatorname{Vol} N_{t-4}$ & & & $0.2523(2.221)$ & $0.2311(2.020)$ \\
\hline$c$ & $-0.0018(-0.130)$ & $-0.0024(-0.122)$ & $-0.004(-0.271)$ & $-0.005(-0.324)$ \\
\hline$A d j R^{2}$ & 0.9722 & 0.9426 & 0.9525 & 0.9514 \\
\hline $\mathrm{AIC}$ & -0.7148 & 0.0055 & -0.1828 & -0.1675 \\
\hline \multirow[t]{3}{*}{ SC } & -0.6098 & 0.1106 & 0.0080 & 0.0233 \\
\hline & \multicolumn{2}{|c|}{ 5Cities: VAR(3) } & \multicolumn{2}{|c|}{ NMetro: VAR(3) } \\
\hline & $g N_{t}$ & $\operatorname{Vol} N_{t}$ & $g N_{t}$ & $\operatorname{Vol} N_{t}$ \\
\hline$g N_{t-1}$ & $1.2760(15.196)$ & $0.4633(3.173)$ & $1.3204(15.576)$ & $0.5036(3.147)$ \\
\hline$g N_{t-2}$ & $0.0377(0.271)$ & $-0.2911(-1.206)$ & $-0.1103(-0.775)$ & $-0.1269(-0.472)$ \\
\hline$g N_{t-3}$ & $-0.3760(-4.592)$ & $-0.1637(-1.150)$ & $-0.2735(-3.313)$ & $-0.2807(-1.801)$ \\
\hline $\operatorname{Vol} N_{t-1}$ & $0.1287(2.464)$ & $1.1885(13.077)$ & $0.1002(2.144)$ & 1.0469 (11.868) \\
\hline $\operatorname{Vol} N_{t-2}$ & $-0.1034(-1.316)$ & $-0.2791(-2.041)$ & $-0.0191(-0.285)$ & $-0.1519(-1.199)$ \\
\hline $\operatorname{Vol} N_{t-3}$ & $-0.0035(-0.068)$ & $-0.0284(-0.313)$ & $-0.0582(-1.240)$ & $-0.0949(-1.072)$ \\
\hline$c$ & $0.0004(0.041)$ & $0.0001(0.008)$ & $-0.0004(-0.033)$ & $0.0047(0.202)$ \\
\hline$A d j R^{2}$ & 0.9818 & 0.9446 & 0.9790 & 0.9260 \\
\hline $\mathrm{AIC}$ & -1.1058 & 0.0003 & -0.9675 & 0.3026 \\
\hline SC & -0.9581 & 0.1481 & -0.8197 & 0.4504 \\
\hline
\end{tabular}

1) According to the lag(p) selection criteria, we selected $\operatorname{VAR}(2)$ model in Total, VAR(4) model in Smetro, VAR(3) model in 5Cities and Nmetro.

2) Numbers in the parenthesis represent t statistics.

Total: whole contury; Smetro: Seoul Metropolitan area; 5Cities: 5 big cities; NMetro: nonmetropolitan. 
confirm that the movement of trading volume slightly precedes that of housing price change rates. The long-term common cycles in both $\mathrm{gN}$ and VolN had upward movement from trough to peak during 2018. But, the movement direction is forecasted to be changed from peak to trough after 2019 to the end of 2020. The forecast values from $\operatorname{VAR}(2)$ model also show downward direction after 2019.

What to think about when interpreting the cycle analysis results of this study is the point that the housing price has long term upward trend.8) Therefore, it should be interpreted that lowering after the cycle reaches its peak does not mean a recession in the housing market or a decline in housing prices, but at this point, housing prices still rise but the speed of increase decreases relatively. Conversely, it can be interpreted that when the cycle reaches its trough and then switches to the peak direction, the volume of transactions increases, followed by a relatively faster speed of increase in housing prices.

Considering these point, combining the forecast results of harmonic analysis and VAR(2) model, the housing market is expected to face a slow speed of increase in housing sales prices for the time being after 2019. But after the end of 2020, housing price is expected to be switched to a relatively rapid increase again.

\section{2) Housing market in Seoul metropolitan area}

In the aspect of long-term common cycles in $\mathrm{gN}$ and VolN in SMetro, we could also confirm that the movement of trading volume

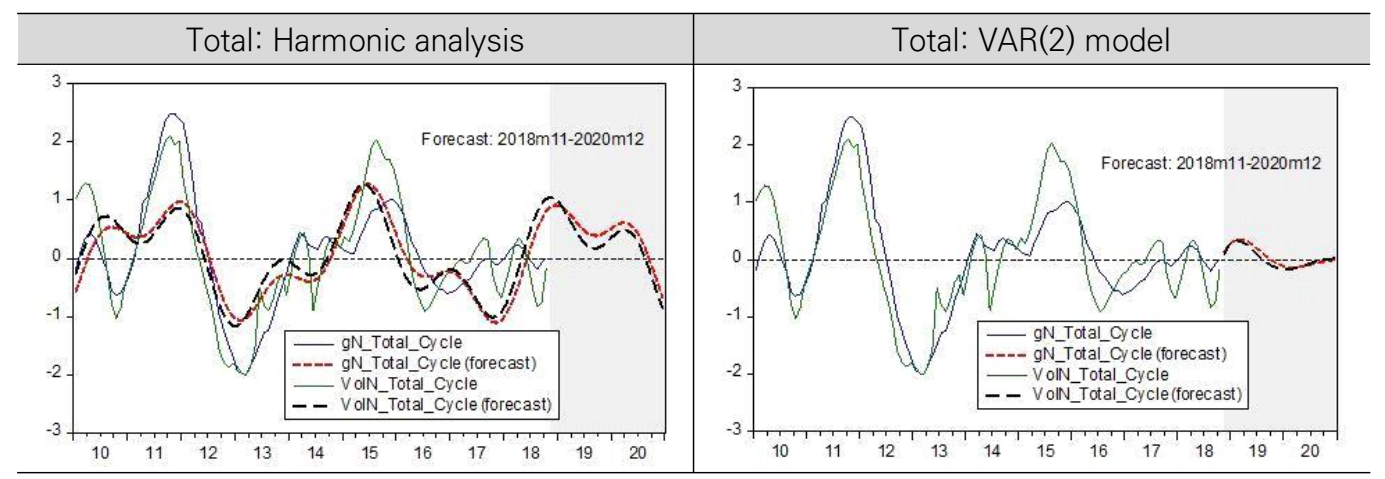

Total: whole contury.

〈Figure 4〉 Forecasting results: Total (forecast: 11.2018-12.2020)

8) So, the periodic observation about the change in long term trend in housing price is also needed to do comprehensive judgement about housing market business cycle in addition to the analysis of cycles in housing price and trading volume ( $\mathrm{Ma}, 2016)$. 


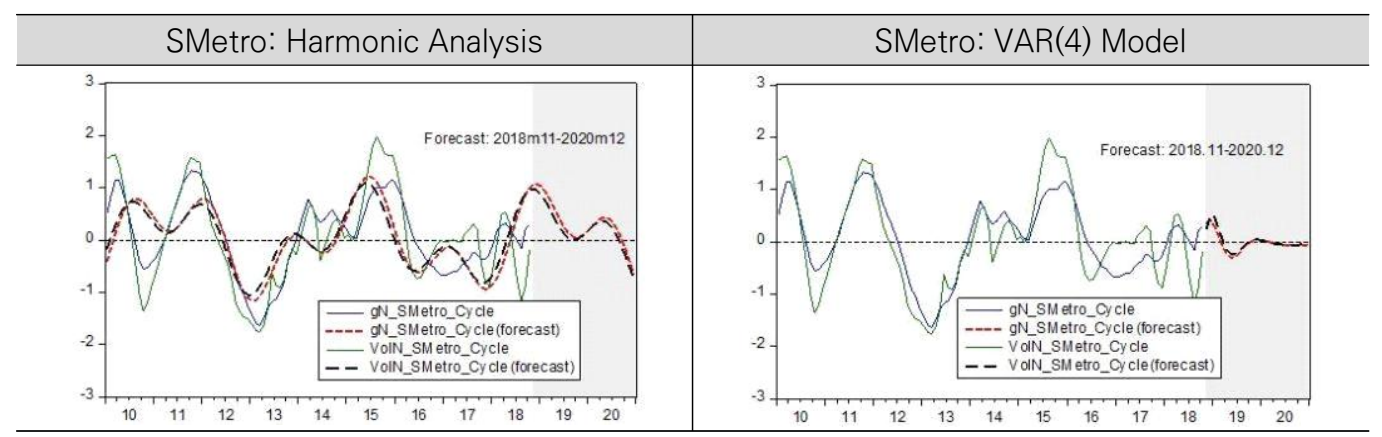

SMetro: Seoul Metropolitan area.

〈Figure 5〉 Forecasting results: SMetro (forecast: 11.2018-12.2020)

slightly precedes that of housing price change rates. The long-term common cycles in both $\mathrm{gN}$ and VolN had upward movement from trough to peak during 2018. But, the movement direction is forecasted to be changed from peak to trough after 2019 to the end of 2020. The results in SMetro are similar to those in whole country. The forecast values from VAR(4) model also show downward direction after 2019 and the speed of downward in Smetro is faster than that in whole country.

Combining the forecast results of harmonic analysis and VAR(4) model, it is expected that the housing market in the metropolitan area will face a slow speed of increase in housing price for the time being after 2019. But after the end of 2020, housing price is expected to be switched to a relatively rapid increase again.

\section{3) Housing market in 5 big cities area}

In the aspect of long-term common cycles in $\mathrm{gN}$ and VolN in 5Cities, we could also confirm that the movement of trading volume slightly precedes that of housing price change rates. The long-term common cycles in both $\mathrm{gN}$ and VolN had upward movement from trough to peak during 2017 to 2019. But, the movement direction is forecasted to be changed from peak to trough after the middle of 2019 to the end of 2020. The forecast values from VAR(3) model also show downward diretion after the middle of 2019 but the magnitude of downward is expected not so significant because the recent amplitude of the cycles was relatively small in 5Cities.

Combining the forecasted results of harmonic analysis and VAR(3) model, it is expected that the housing market in the 5 big cities will face a slow speed of increase in housing price for the time being after 2019. But after the end of 2020, housing price is expected to be switched to a relatively rapid increase again. The results in 5 big cities also are similar to 


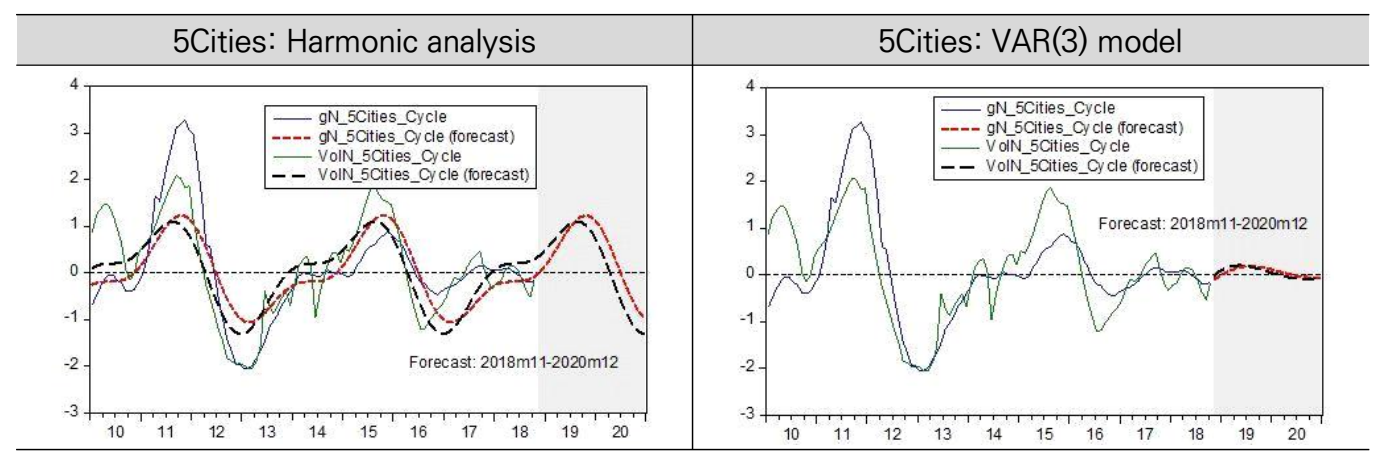

5Cities: 5 big cities.

〈Figure 6〉 Forecasting results: 5Cities (forecast: 11.2018-12.2020)

those in whole country.

\section{4) Housing market in non-metropolitan area}

In the aspect of long-term common cycles in $\mathrm{gN}$ and VolN in NMetro, we could confirm that the two variables move similarly but could not say that the movement of trading volume precedes that of housing price change rates. The long-term common cycles in both $\mathrm{gN}$ and VolN had upward trends after 2018.
But, the movement direction is forecasted to be changed from peak to trough after the middle of 2020. The forecasted values from VAR(3) model also show downward direction after the middle of 2019 but the magnitude of upward or downward is expected not so significant because the recent amplitude of the cycles was relatively small in NMetro area.

Combining the forecast results of harmonic analysis and VAR(3) model, it is expected that the movement of housing prices in another

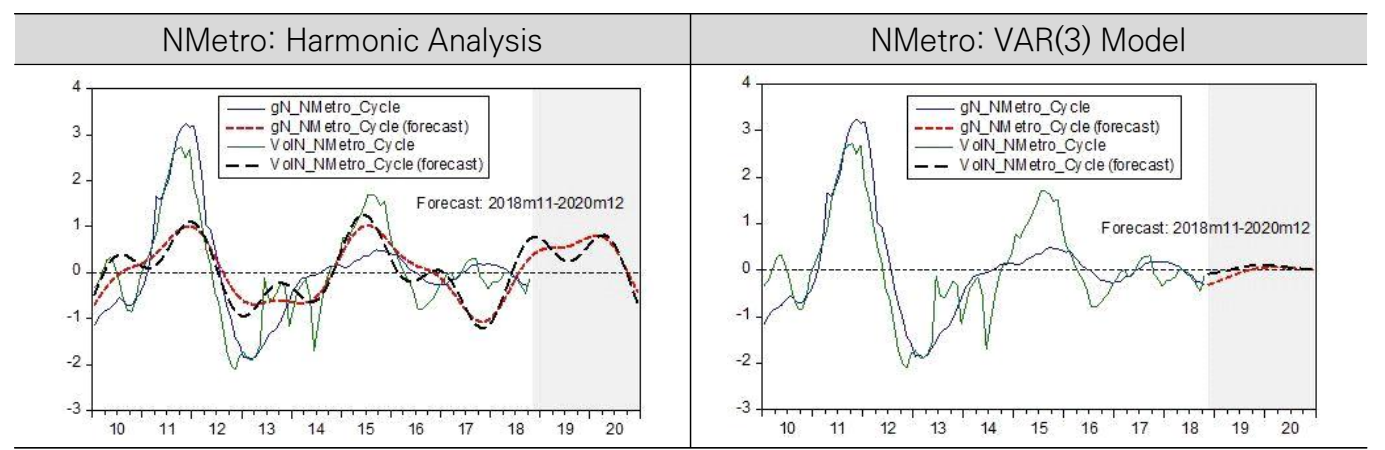

NMetro: non- metropolitan.

〈Figure 7〉 Forecasting results: NMetro (forecast: 11.2018-12.2020) 
housing market slightly precedes that in NMetro housing market. This result implies that regional housing markets can be devided into several submarkets.

\section{Conclusion}

We can say that the movements of housing prices and trading volume have long-term cycles. So, we can presume that there would be a close relationship between cyclic components embedded in these two variables. But, until now, it is difficult to find studies which analyzed cyclical characteristics and the relationship in the aspect of common cycles embedded in these two variables. In this analysis, unlike the previous studies conducted to confirm the correlation and lead-lag relationship between housing prices and trading volume using the methodologies in time domain analysis, we tried to interpret from different points of view through analyzing cyclical characteristics embedded in these two variables by using spectral analysis in frequency domain. When we forecast cycles in housing prices and trading volume, for the purpose of comparison, we added the results of $\operatorname{VAR}(\mathrm{p})$ model analysis in time domain in addition to the results of the spectral analysis in frequency domain. After identifying common cycles embedded in these two variables, we could confirm a close relationship in the aspect of common cycles. And then, we could confirm the current position of two variables in the aspect of long-term cycles and could forecast future direction of the cycles.

In our analysis, we could confirm that the movement of trading volume slightly precedes that of housing price change rates. The longterm common cycles in both time series had upward movement from trough to peak during 2018. But, the movement direction is forecasted to be changed from peak to trough after 2019 to the end of 2020. Considering the point that the housing price has long term upward trend, it should be interpreted that lowering after the cycle reaches its peak does not mean a recession in the housing market or a decline in housing prices, but at this point, housing prices still rise but the speed of increase decreases relatively. And when the cycle reaches its trough and then switches to the peak direction, we can say that the volume of transactions increases, followed by a relatively faster speed of increase in housing prices. So, the results of our analysis show that housing market was expected to face a slow speed of increase in housing prices while decrease in trading volume for the time being after 2019. But after the end of 2020, both trading volume and housing price were expected to be switched to a relatively rapid increase again. 
Meanwhile, in our analysis, we used the data from 2007.01-2018.10 and showed the forecast result after 11.2018. So, by passage of time, it is necessary to conduct the analysis periodically with updated data. Plus, it is also necessary to conduct spectral analysis to confirm the relationship among housing price, trading volume, and other variables such as interest rate at the same time. Ultimately, as we can see from the results of this analysis, we could improve the rationality about the forecasting results of future cycles by confirming the results from time domain and frequency domain analysis concurrently.

\section{References}

Cho, D., \& Ma, S. (2006). Dynamic relationship between housing values and interest rates in the Korean housing market. The Journal of Real Estate Finance and Economics, 32(2), 169-184.

Clayton, J., Miller, N., \& Peng, L. (2010). Price-volume correlation in the housing market: Causality and co-movements. The Journal of Real Estate Finance and Economics, 40(1), $14-40$.

Diebold, F. X. (2001). Elements of forecasting (2nd ed.). Mason, OH: South-Western.

Genesove, D., \& Mayer, C. (2001). Loss aversion and seller behavior: Evidence from the housing market. The Quarterly Journal of Economics, 116(4), 1233-1260.

Leung, C. K. Y., \& Feng, D. (2005). What drives the property price-trading volume correlation? Evidence from a commercial real estate market. The Journal of Real Estate Finance and Economics, 31(2), 241-255.

Lim, D. (2014). The research on housing transaction volume and housing prices with focus on local taxes. Real Estate Journal, 58, 195-208.

Lim, J. (2011). Do housing trading volume explain housing prices or the converse. The Korea Spatial Planning Review, 69, 3-18.

Ma, S. (2016). Cyclical characteristics of housing market. Journal of the Korean Real Estate Association, 34(2), 197-216.

Stein, J. C. (1995). Prices and trading volume in the housing market a model with downpayment effects. The Quarterly Journal of Economics, 110(2), 379-406.

Warner, R. M. (1998). Spectral analysis of timeseries data. New York, NY: Guilford Press.

Wei, W. W. (1990). Time series analysis. Boston, MA: Addison-Wesley.

논문접수일: 2021.12.11 논문심사일: 2021.12.15 게재확정일: 2021.12.20 


\section{Appendix 1. Periodogram}

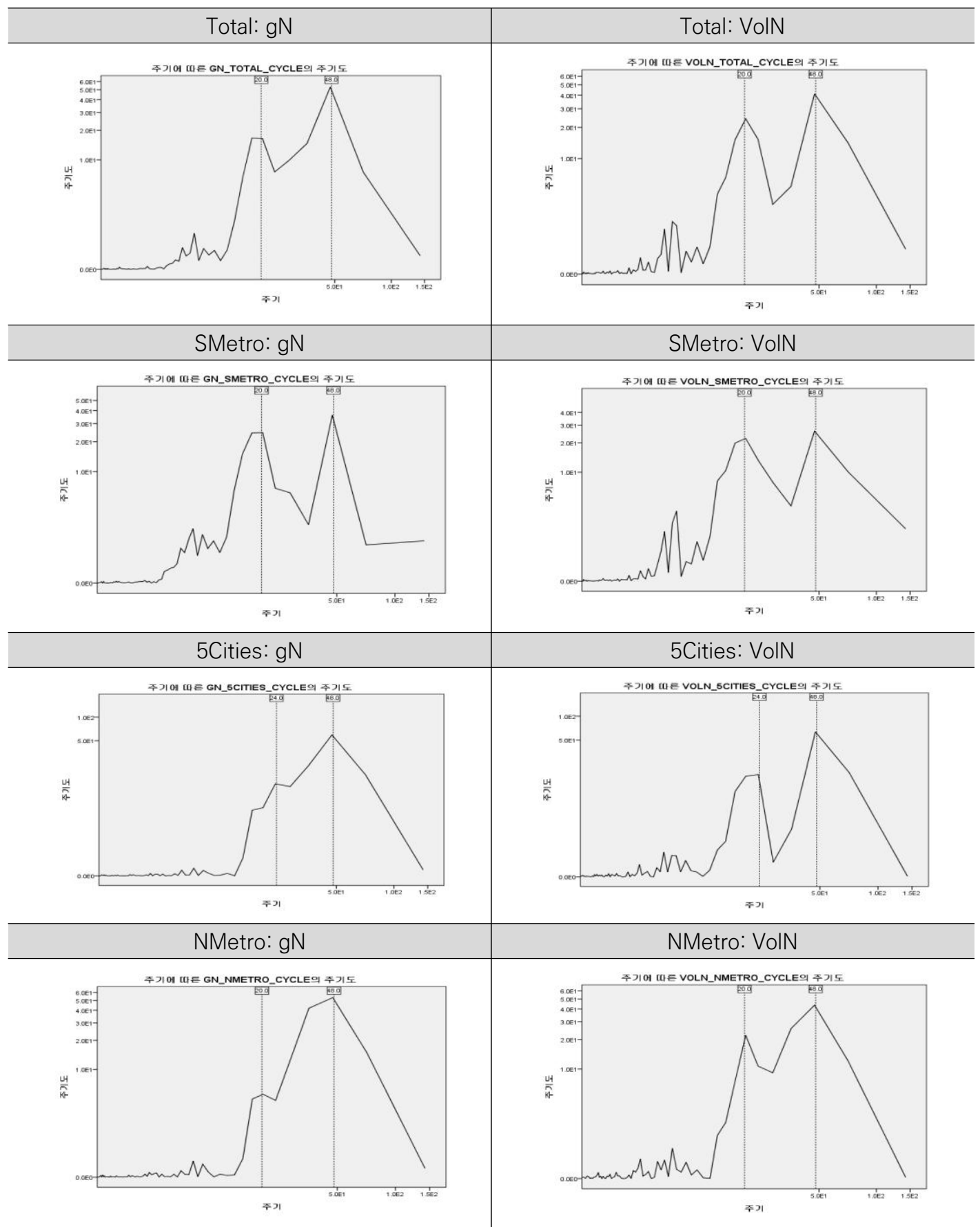

Total: whole contury; SMetro: Seoul Metropolitan area; 5Cities: 5 big cities; NMetro: nonmetropolitan. 


\section{Appendix 2. Phase and squared coherence}

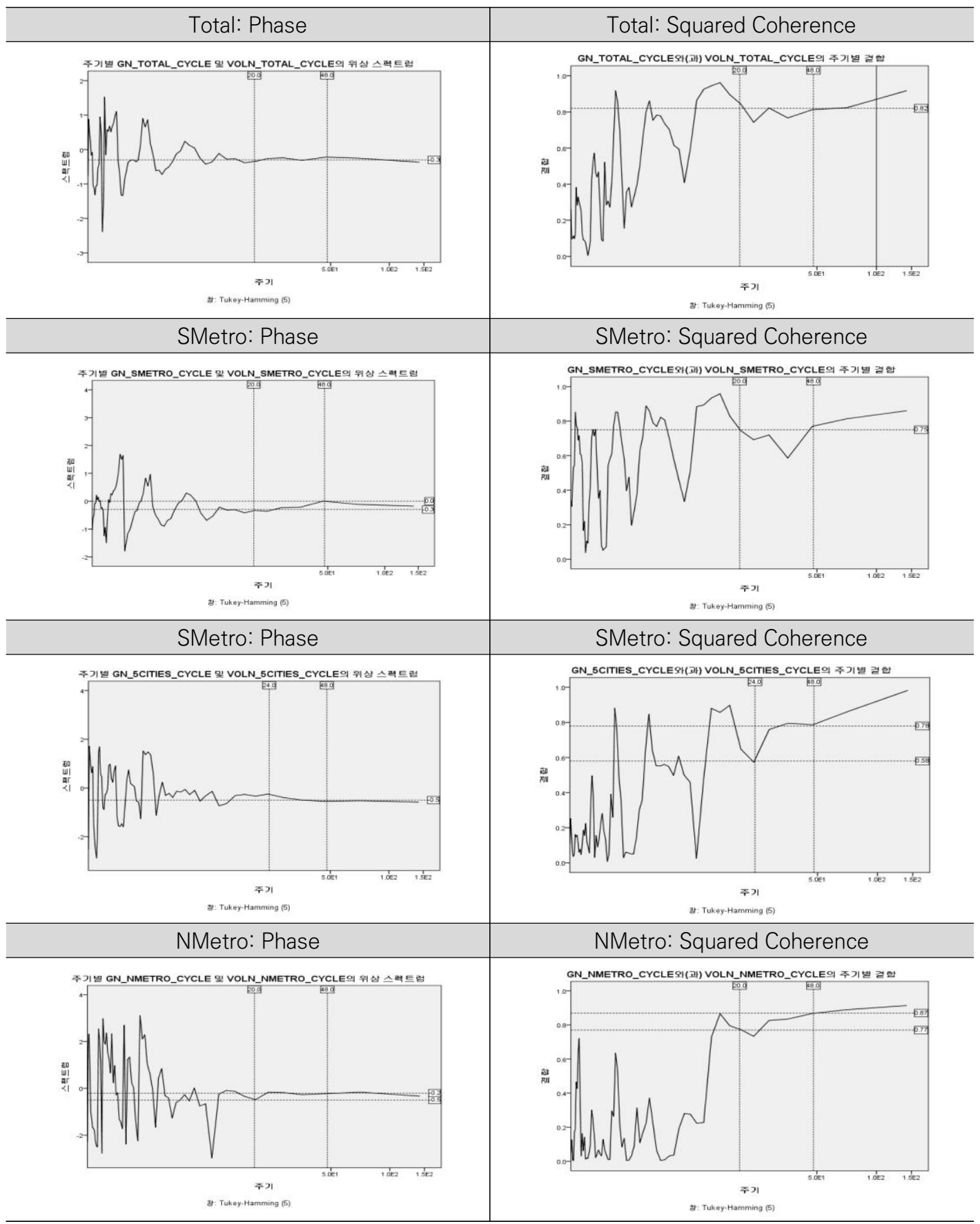

Total: whole contury; SMetro: Seoul Metropolitan area; 5Cities: 5 big cities; NMetro: nonmetropolitan. 
Journal of Housing and Urban Finance 2021; 6(2):53-73

pISSN: 2508-3872 | elSSN: 2733-4139

https://doi.org/10.38100/jhuf.2021.6.2.53

\section{빈도영역 분석법을 통한 주택가격과 거래량의 공통 사이클 분석}

\section{마승렬*}

\section{Abstract}

주택가격과 주택거래량의 움직임에는 장기적인 사이클이 존재하는 것으로 알려져 있다. 따라서 이들 시계열의 사이클간에는 밀접한 관련성이 있을 것으로 추정해 볼 수 있다. 그러나 이들 시계열에 내재되어 있는 공통적인 사이클 성분을 분석하고, 공통적 사이클 하에서의 밀접한 관련성에 대하여 분석한 연구는 아직까지 찾아보기 어렵다. 본 연구는 이들 시계열간의 선후행관계를 시간영역에서의 방법론을 이용하여 분석한 선행연구들과는 달리 빈도영역에서의 분석법인 스펙트럴분석법을 이용하여 이들 시계열에 내재되어 있는 순환주기 특성을 분 석하였다. 아울러 시간영역에서의 분석법을 이용한 분석결과와 비교하기 위한 목적으로 양 시계열의 사이클 예 측에 $\operatorname{VAR}(\mathrm{p})$ 모형에 의한 분석도 병행하였다. 본 연구의 분석결과에 의하면 공통적인 순환주기 하에서 주택거 래량이 주택가격의 변화에 조금 선행하는 움직임을 가지고 있음을 확인할 수 있었다. 사이클 예측치는 주택가 격이 장기적인 상향추이를 가지고 있는 상황에서 2019년도 이후에는 거래량이 감소하면서 주택가격상승률이 둔화되지만 2020년도 말 이후에는 거래량과 주택가격상승률이 다시 빠르게 상승하는 국면으로 전환될 것이라 는 예측결과를 보여주었다. 궁극적으로 시간영역에서의 분석과 빈도영역에서의 분석을 동시에 시행하여 이들 분석결과를 함께 이용한다면 미래 사이클의 예측에 대한 합리성을 높일 수 있을 것이다.

주제어: 공통 사이클, 주택가격, 거래량, 스펙트럴분석, 조화분석

\footnotetext{
* 손사경 영연구소 소장, E-mail: samhan12@hanmail.net

(c) Copyright 2021 Korea Housing \& Urban Guarantee Corporation. This is an Open Access article distributed under the terms of the Creative Commons Attribution Non-Commercial License (http://creativecommons.org/licenses/by-nc/4.0/) which permits unrestricted non-commercial use, distribution, and reproduction in any medium, provided the original work is properly cited.
} 